\title{
Container volume and controlled-release fertilizer influence the seedling quality of Agonandra brasiliensis ${ }^{1}$
}

\author{
Oscar José Smiderle², Raiovane Araújo Montenegro³, \\ Aline das Graças Souza ${ }^{4}$, Edvan Alves Chagas ${ }^{2}$, Thiago Jardelino Dias ${ }^{5}$
}

\section{ABSTRACT}

Agonandra brasiliensis is a tree from tropical forests, with a wide occurrence in the Brazilian Savannah region. Despite its potential as wood and for reforestarion, efficient protocols for its seedling production are still lacking. This study aimed to assess morphological characteristics for the seedling quality of $A$. brasiliensis, under nursery conditions, as a function of container volume and controlled-release fertilizer dose. The experiment was carried out in a 2 × 5 factorial scheme, testing two container volumes $(1.8 \mathrm{~L}$ and $2.2 \mathrm{~L})$ and five doses $\left(0 \mathrm{~g} \mathrm{~L}^{-1}\right.$, $1 \mathrm{~g} \mathrm{~L}^{-1}, 2 \mathrm{~g} \mathrm{~L}^{-1}, 4 \mathrm{~g} \mathrm{~L}^{-1}$ and $\left.8 \mathrm{~g} \mathrm{~L}^{-1}\right)$ of the encapsulated fertilizer Forth Cote TM $^{\mathrm{TM}}$ (formulation NPK 15-09-12). The plots consisted of five homogeneous seedlings transplanted in polyethylene bags $(15 \mathrm{~cm} \times 35 \mathrm{~cm})$ with washed medium sand substrate. The following characteristics were measured: shoot length; stem diameter; increases in length and diameter; total dry matter; shoot and root dry matters and the ratio between them. The Dickson Quality Index was also obtained. The seedling quality for morphological traits, such as shoot length, stem diameter and total dry matter, was especially favoured by treatments combining the controlled-release fertilizer at a dose around $5.0 \mathrm{~g} \mathrm{~L}^{-1}$ and container volume of $2.2 \mathrm{~L}$.

KEYWORDS: Pau-marfim, encapsulated fertilizer, Brazilian Savannah.

\section{INTRODUCTION}

The forestry sector can be described as an important component of the Brazilian economy, as it contributes significantly to the generation of products, taxes, jobs and income (CNI 2017). The continuing expansion of this sector has driven forest investors to opt for the cultivation of native species

\section{RESUMO}

Volume de recipiente e fertilizante de liberação controlada afetam a qualidade de mudas de Agonandra brasiliensis

Agonandra brasiliensis é uma árvore de florestas tropicais, com ampla ocorrência na região do Cerrrado brasileiro. Apesar do seu potencial como madeira e para reflorestamento, eficientes protocolos para a produção de mudas ainda estão em falta. Objetivouse avaliar características morfológicas para a qualidade de mudas de A. brasiliensis, em condições de viveiro, em função do volume do recipiente e dose de fertilizante de liberação controlada. O experimento foi realizado em esquema fatorial $2 \times 5$, testando-se dois volumes $(1,8 \mathrm{~L}$ e 2,2 L) de recipiente e cinco doses $\left(0 \mathrm{~g} \mathrm{~L}^{-1}, 1 \mathrm{~g} \mathrm{~L}^{-1}, 2 \mathrm{~g} \mathrm{~L}^{-1}, 4 \mathrm{~g} \mathrm{~L}^{-1} \mathrm{e}\right.$ $8 \mathrm{~g} \mathrm{~L}^{-1}$ ) do fertilizante encapsulado Forth Cote $^{\circledR}$ (formulação NPK 15-09-12). As parcelas constituíram-se de cinco mudas homogêneas transplantadas em sacos de polietileno $(15 \mathrm{~cm}$ x $35 \mathrm{~cm})$ com substrato de areia média lavada. As seguintes características foram mensuradas: comprimento da parte aérea; diâmetro do caule; incrementos em comprimento e diâmetro; matéria seca total; matéria seca da parte aérea e da raiz e a razão entre elas. Também foi determinado o Índice de Qualidade de Dickson. A qualidade das mudas para caracteres morfológicos como comprimento da parte aérea, diâmetro de caule e matéria seca total foi especialmente favorecida por tratamentos que combinaram o fertilizante de liberação controlada em dose aproximada de 5,0 $\mathrm{g} \mathrm{L}^{-1}$ e recipiente com volume de $2,2 \mathrm{~L}$.

PALAVRAS-CHAVE: Pau-marfim, fertilizante encapsulado, Cerrrado.

(Beling 2016, IBÁ 2017) and, as such, there is now a challenge to meet the demand for high-quality seedlings of suitable nutritional status to setup reforestation areas with economic purposes.

Among the potential species for use in reforestation in the north of Brazil is Agonandra brasiliensis Miers ex Benth. \& Hook. f., which belongs to the Opiliaceae family and is locally known

${ }^{1}$ Received: Jan. 31, 2020. Accepted: June 03, 2020. Published: July 21, 2020. DOI: 10.1590/1983-40632020v5062134.

${ }^{2}$ Empresa Brasileira de Pesquisa Agropecuária (Embrapa Roraima), Boa Vista, RR, Brasil.

E-mail/ORCID: oscar.smiderle@embrapa.br/0000-0001-6692-1329, edvan.chagas@embrapa.br/0000-0001-8604-7819.

${ }^{3}$ Universidade Federal de Roraima, Boa Vista, RR, Brasil. E-mail/ORCID: raiovane@hotmail.com.br/0000-0003-4606-0650.

${ }^{4}$ Faculdade Roraimense de Ensino Superior, Boa Vista, RR, Brasil. E-mail/ORCID: alineufla@hotmail.com/0000-0001-8158-5933.

${ }^{5}$ Universidade Federal da Paraíba, Departamento de Ciências Vegetais e Ambientais, Areia, PB, Brasil.

E-mail/ORCID: thiagojardelinodias@gmail.com/0000-0002-7843-6184. 
as "pau-marfim", being distributed from Mexico to the north of Argentina (Souza et al. 2020). In Brazil, this plant occurs in Cerrado and Cerradão areas, in the states of Roraima, Amazonas, Acre, Rondônia, Bahia, Ceará, Espírito Santo, Goiás, Maranhão, Mato Grosso, Mato Grosso do Sul, Minas Gerais, Pará, Piauí and São Paulo, being also present in the Federal District (Souza et al. 2020).

Its wood is widely used in the construction and furniture industries. In folk medicine, its leaves are used in baths for the treatment of rheumatism, and the oil extracted from its seeds and barks is indicated for healing scars and treating bronchitis (Moares et al. 2018).

In addition, there is a lack of information on A. brasiliensis in the domestic and international literature that might provide important methods and techniques of preservation and propagation. Native forest species, whether for purposes of production or preservation, depend largely on the use of seedlings produced in containers (Massad et al. 2017).

The use of containers, concerning their volume, has some advantages, such as a better-quality root system, greater degree of mechanization, lower consumption of substrate, higher seedling production per unit area and lower transportation costs (Matias et al. 2019). The use of containers for seedling production, therefore, depends on the quality of the substrate. According to Smiderle et al. (2017), with a slow initial growth, some native forest species from the Roraima state need more time in the nursery to reach the desired minimum size, what, in turn, leads to the use of larger containers and the addition of the appropriate fertilizer.

Brito et al. (2018) point out that the total nutrient-release time for an encapsulated fertilizer as Forth Cote ${ }^{\mathrm{TM}}$, for example, in the NPK formulation 15-10-10, may vary from 2 to 15 months, what allows the traditional dose of nitrogen fertilizer to be reduced from $15 \%$ to $20 \%$, due to the increase in the nutrient use efficiency of the plants.

It should be noted that, for some plant species, slow-release fertilizers have shown negative effects. Serrano et al. (2013), when evaluating the production of early dwarf cashew 'CCP-06' seedlings, observed a reduction in the seedling growth by increasing the doses of another controlled-release fertilizer (Osmocote ${ }^{\mathrm{TM}}$ at a 14-14-14 formulation). Even before, Serrano et al. (2012) found that the growth characteristics of cashew 'CCP 06' seedlings were also negatively influenced by increases in the doses of this fertilizer in the NPK formulation 15-09-12. Studies of this nature show the need of determining appropriate doses for these fertilizers, including other NPK formulations and container volumes; both of which need to be determined for the seedling production of native species from Savannah and tropical forests.

Thus, this study aimed to assess morphological characteristics for the seedling quality of $A$. brasiliensis, under nursery conditions, as a function of the container volume and doses of a controlledrelease fertilizer.

\section{MATERIAL AND METHODS}

The research was carried out in a seedling nursery and under laboratory conditions at the Embrapa Roraima, in Boa Vista, Roraima state, Brasil, from September 2018 to June 2019. A. brasiliensis was the species used, and seeds were collected from 15 tree populations in the reproduction stage, in an area of submontane dense ombrophilous forest (1'38'29"N and 60 $\left.58^{\circ} 11^{\prime \prime} \mathrm{W}\right)$, with an emerging canopy, in Caracaraí, Roraima state, in March 2018. The fruits were collected manually from the trees and taken to the laboratory, where they were washed in running water, being the damaged fruits discarded.

After obtaining the seeds, they were processed and then sown in a seedbed that contained washed medium sand as substrate, for the germination and initial development of the seedlings. The substrate moisture was maintained by manual irrigation, four times a day.

The experimental design was completely randomized, in a $2 \times 5$ factorial scheme, with five replications. The treatment factors were two container volumes $(1.8 \mathrm{~L}$ and $2.2 \mathrm{~L})$ and five doses $\left(0 \mathrm{~g} \mathrm{~L}^{-1}\right.$, $1 \mathrm{~g} \mathrm{~L}^{-1}, 2 \mathrm{~g} \mathrm{~L}^{-1}, 4 \mathrm{~g} \mathrm{~L}^{-1}$ and $\left.8 \mathrm{~g} \mathrm{~L}^{-1}\right)$ of the commercial controlled-release fertilizer Forth Cote ${ }^{\mathrm{TM}}$, in the formulation NPK 15-09-12. Each plot consisted of five seedlings (one in each container).

Approximately at thirty days after sowing, the process of seedling emergence began. Once the seedlings had reached a homogeneous height of around $12.0 \mathrm{~cm}$, they were transplanted to polyethylene bags $(15 \mathrm{~cm} \times 35 \mathrm{~cm})$ containing washed medium sand as substrate (Table 1). Doses of the encapsulated controlled-release fertilizer (Forth Cote $^{\mathrm{TM}}$ ), in NPK formulation 18-05-09, were 
Table 1. Chemical composition of the medium-sand substrate used for the production of Agonandra brasiliensis seedlings.

\begin{tabular}{|c|c|c|c|c|c|c|c|c|c|c|c|c|c|}
\hline \multirow{2}{*}{$\mathrm{pH}$} & $\mathrm{OM}^{*}$ & V & $\mathrm{Al}$ & $\mathrm{H}+\mathrm{Al}$ & SB & CEC & $\mathrm{P}$ & K & $\mathrm{Ca}$ & $\mathrm{Mg}$ & $\mathrm{Zn}$ & $\mathrm{Fe}$ & $\mathrm{Mn}$ \\
\hline & \multicolumn{2}{|c|}{$-(\%)$} & & & & $-\mathrm{cmc}$ & $\mathrm{m}^{-3}$ & & & & & $\mathrm{~g} \mathrm{dm}$ & \\
\hline 5.7 & 0.51 & 40.0 & 0.10 & 0.30 & 0.2 & 0.5 & 0.27 & 0.00 & 0.10 & 0.10 & 4.1 & 84.2 & 52.1 \\
\hline
\end{tabular}

incorporated into the surface, according to each treatment. The plants were then placed under $50 \%$ of shade in a roofed nursery and irrigated by sprinklers for five minutes, three times a day.

The following morphological characteristics of the seedlings were evaluated: shoot length (measured with a graduated rule); stem diameter (with a digital calliper); shoot dry weight $\left(\mathrm{g}_{\text {plant }}{ }^{-1}\right)$; and root dry weight $\left(\mathrm{g} \mathrm{plant}^{-1}\right)$. The shoot and root dry matters were determined from material dried in an oven at $65^{\circ} \mathrm{C}$, for 72 hours. From these two variables, data for total dry weight $\left(\mathrm{g} \mathrm{plant}^{-1}\right)$ were obtained, taken as a simple sum of the values, and also the shoot and root dry matters ratio, determined by simple division. The Dickson Quality Index for seedlings was determined as a function of the shoot length, stem diameter, and shoot and root dry matters (Dickson et al. 1960). In addition, the increases in the shoot length and stem diameter were obtained from the difference between the respective values, for each seedling of the plot, at 240 days after transplanting (DAT) and the day when it occurred (0 DAT).

To verify the assumptions of the analysis of variance (Anova), the data were checked for normality by the Shapiro-Wilk test and for homoscedasticity by the Bartlett test. When these assumptions were met, the Anova was applied to test the principal and interactions effects. The responses of seedling quality to the fertilizer doses were estimated by polynomial regression, with choice of models based on the significance of the parameters estimates and $\mathrm{R}^{2}$ values. All tests were applied at $5 \%$ of significance, and analyses were carried out using the Sisvar statistical software (Ferreira 2014).

\section{RESULTS AND DISCUSSION}

At the end of the experiment (240 days after transplanting), the survival rate of the $A$. brasiliensis seedlings was $100 \%$ for all treatments. The summary of the analyses of variance shows that there was no significant $(\mathrm{p}>0.05)$ interaction between the treatment factors, for all evaluated variables (Table 2). Therefore, it is possible to investigate the effects of each factor separately.

The evaluated morphological variables of growth in shoot length and stem diameter displayed a quadratic response in fitting the regression analysis equations (Figures 1A and 1B), showing that the highest tested fertilizer dose $\left(8.0 \mathrm{~g} \mathrm{~L}^{-1}\right)$ results in a decrease for both variables. As such, for plant height, it was found that, regardless of container volume, there was growth of the seedlings with the increase in the controlled-release fertilizer dose, with a quadratic

Table 2. Summary of the analyses of variance with mean squares and respective significances of the variation sources tested for morphological variables associated with the seedling quality of Agonandra brasiliensis, in response to doses of a controlledrelease fertilizer and two container volumes, at 240 days after transplanting.

\begin{tabular}{|c|c|c|c|c|}
\hline \multirow{2}{*}{ Variable } & \multicolumn{3}{|c|}{ Sources of variation } & \multirow{2}{*}{$\mathrm{CV}(\%)$} \\
\hline & Dose (D) $(\mathrm{df}=4)^{1}$ & Volume $(\mathrm{V})(\mathrm{df}=1)$ & $\mathrm{D} \times \mathrm{V}$ interaction $(\mathrm{df}=4)$ & \\
\hline Shoot length $(\mathrm{cm})$ & $859.850 * *$ & $286.2700^{\mathrm{ns}}$ & $129.6000^{\mathrm{ns}}$ & 13.60 \\
\hline Stem diameter $(\mathrm{mm})$ & $4.266^{* *}$ & $2.9700 * *$ & $0.0415^{\mathrm{ns}}$ & 14.80 \\
\hline Increase in shoot length $(\mathrm{cm})$ & $924.080 * *$ & $90.0000^{\mathrm{ns}}$ & $138.0600^{\mathrm{ns}}$ & 23.05 \\
\hline Increase in stem diameter (mm) & $4.488 * *$ & $1.9800 * *$ & $0.1920^{\mathrm{ns}}$ & 10.48 \\
\hline Shoot dry matter $\left(\right.$ g plant $\left.^{-1}\right)$ & $40.540 * *$ & $75.7300 * *$ & $10.3400^{\mathrm{ns}}$ & 23.14 \\
\hline Root dry matter (g plant $\left.{ }^{-1}\right)$ & $73.120 * *$ & $261.3700 * *$ & $12.9800^{\mathrm{ns}}$ & 23.06 \\
\hline Total dry matter $\left(\mathrm{g}_{\text {plant }}{ }^{-1}\right)$ & $230.110 * *$ & $587.5200 * *$ & $40.7300^{\mathrm{ns}}$ & 23.66 \\
\hline Shoot and root dry matter ratio & $0.095 * *$ & $0.0008^{\text {ns }}$ & $0.0013^{\mathrm{ns}}$ & 5.16 \\
\hline Dickson Quality Index & $1.118^{* *}$ & $0.8260 * *$ & $0.0330^{\mathrm{ns}}$ & 9.88 \\
\hline
\end{tabular}

${ }^{\mathrm{ns}}$ and ${ }^{* *}$ : not significant $(\mathrm{p}>0.05)$ and significant values $(\mathrm{p}<0.01)$, respectively, by the F-test. ${ }^{1} \mathrm{df}$ : degrees of freedom; CV: experimental coefficient of variation. 

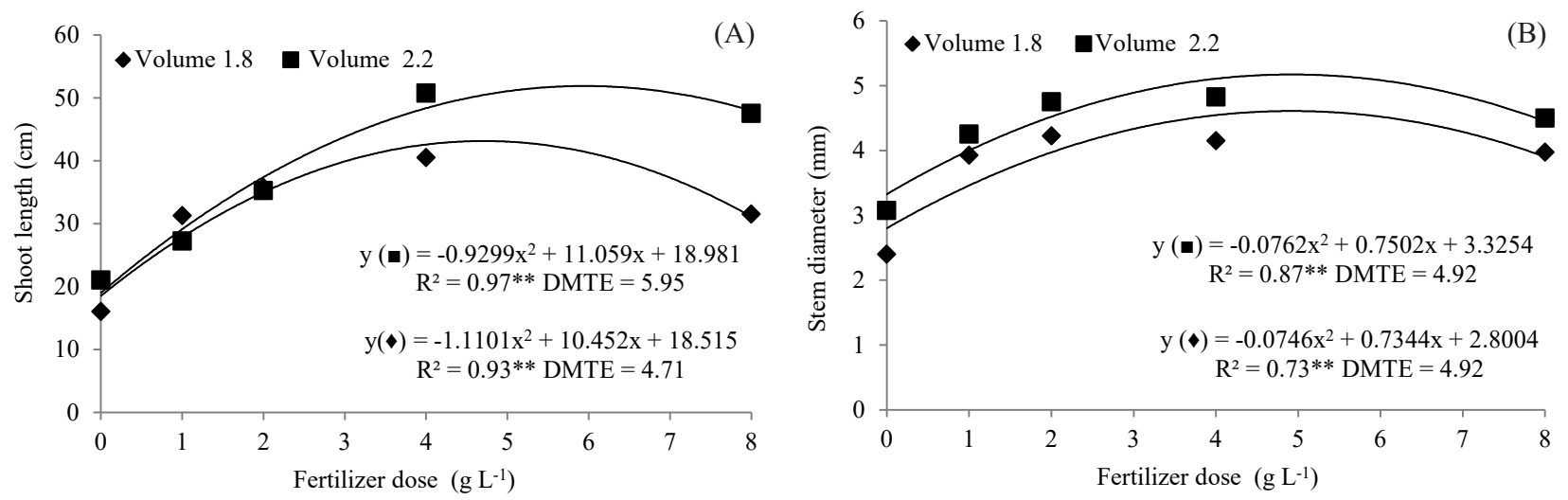

Figure 1. Effect of controlled-release fertilizer doses and container volumes on the shoot length (A) and stem diameter (B) of Agonandra brasiliensis seedlings, under nursery conditions.

response and an average dose of maximum technical efficiency of $5.33 \mathrm{~g} \mathrm{~L}^{-1}$ of fetilizer.

The height of the plants grown in a container volume of $2.2 \mathrm{~L}$ showed a maximum technical efficiency at the dose of $5.95 \mathrm{~g} \mathrm{~L}^{-1}$ of the fertilizer, reaching $51.0 \mathrm{~cm}$ with an increase of $19.6 \%$, when compared to the plants grown in containers of $1.8 \mathrm{~L}$, whose maximum technical efficiency dose was $4.71 \mathrm{~g} \mathrm{~L}^{-1}$ of the fetilizer (Figure 1A). In this case, it is assumed that there is a reciprocal relationship between the controlled-release fertilizer dose and the container volume, that is, in relation to the larger container volume, which increases the amount of substrate exploited, resulting in a greater efficiency of the root system in absorbing nutrients, and promoting an harmonic growth and development among the plant organs. In addition, the maximum values for seedling stem diameter $[4.61 \mathrm{~mm}$ (1.8 L container) and $5.17 \mathrm{~mm}(2.2 \mathrm{~L}$ container $)$ ] were reached at doses of $4.92 \mathrm{~g} \mathrm{~L}^{-1}$ of the controlled-release fertilizer, irrespective of the container volume (Figure 1B).

The greater growth of seedlings submitted to higher fertilizer doses may be explained by the greater height sensitivity, in relation to the nitrogen fertilizer (Cabreira et al. 2017). However, the increasing application of nitrogen may cause the seedling to grow too high, thus resulting in etiolation (Rossa et al. 2013).

In a study on the production of Cedrela fissilis Vell. (Spanish cedar) seedlings, Pias et al. (2015) found a linear increase in diameter with the increase in the length of stay in the nursery, but the seedlings fertilized with Osmocote ${ }^{\mathrm{TM}}$ showed the largest increases. Plants with a larger diameter are better able to survive, given their greater capacity for the formation and growth of new roots (Elli et al. 2013).
Positive results for the variable stem diameter, from using controlled-release fertilizer, were also found in studies with Anadenanthera peregrina and Schinus terebinthifolia Raddi (Rossa et al. 2015), Mimosa scabrella (Stüpp et al. 2015), Peltophorum dubium (Dutra et al. 2016) and Albizia lebbeck (Aguilar et al. 2020).

According to Souza et al. (2018), shoot height, together with collar diameter, is one of the most important morphological characteristics for estimating the growth of forest seedlings after permanent planting in the field. Thus, the greatest increases in height and stem diameter occurred with the fertilizer doses (of maximum technical efficiency) of $6.45 \mathrm{~g} \mathrm{~L}^{-1}$ and $5.86 \mathrm{~g} \mathrm{~L}^{-1}$, respectively, both in the container of 2.2 L. This increase was likely due to the proper dose of slow-release fertilizer and appropriate container volume, the combination of the continuous nitrogen supply to the plant and the local soil or climate factors, such as solar radiation and temperature, resulting in a greater photosynthetic efficiency and the production of new tissues in the plant organs.

Conversely, a smaller increase in the stem diameter was seen in the plants submitted to the dose of $2 \mathrm{~g} \mathrm{~L}^{-1}$, when compared to that of $4 \mathrm{~g} \mathrm{~L}^{-1}$, irrespective of container volume (Figure 2B). According to Souza et al. (2020), this smaller increase in stem diameter may be related to the low availability of nitrogen in the medium-sand substrate, due to its absorption by the plant over time, as well as leaching and other removal processes. The low availability or absence of nitrogen may have reduced the rates of carbon fixation, resulting in restrictions on the production of carbohydrates that might serve as a substrate for the synthesis of new organic molecules and for respiration. 

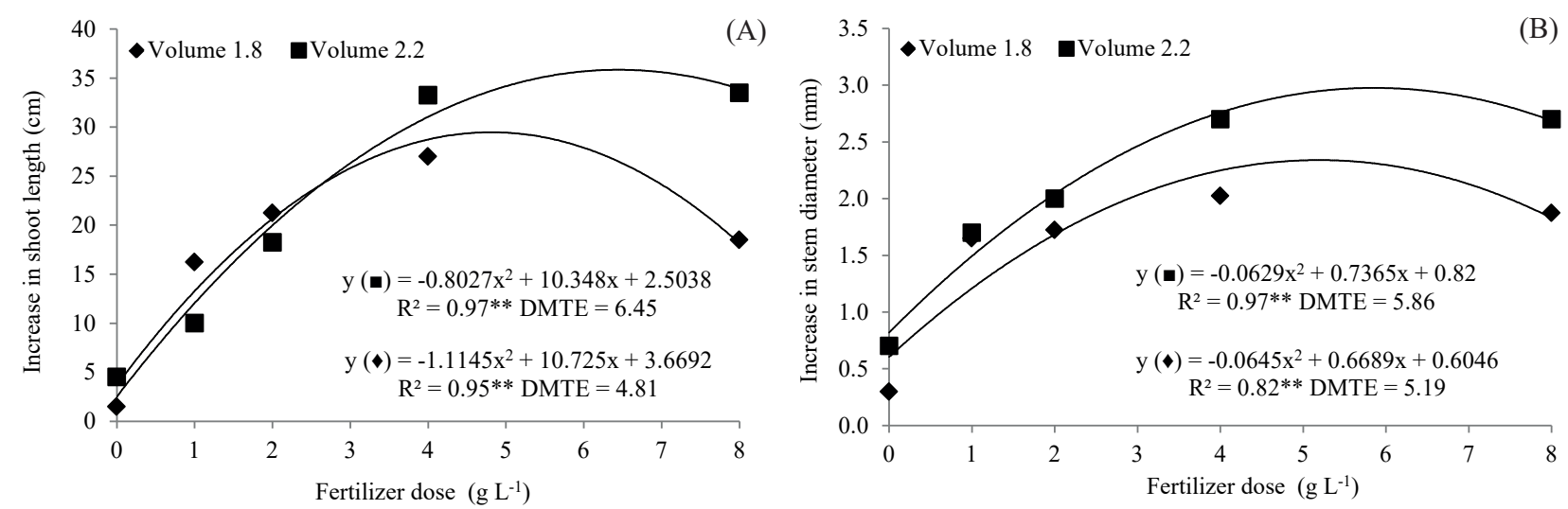

Figure 2. Increases in shoot length (A) and stem diameter (B) of Agonandra brasiliensis seedlings, as a function of controlled-release fertilizer doses and container volumes, under nursery conditions.

With the reduction in carbohydrates, the respiratory process becomes impaired, as respiration is primarily responsible for providing energy for nutrient absorption and maintaining the plant growth rates. As such, it is suggested that the supply of nitrogen from doses of less than $1.0 \mathrm{~g} \mathrm{~L}^{-1}$ might result in disadvantages, such as inferior morphological, physiological and nutritional characteristics in the plants.

However, a positive response was found in other plant organs, such as root dry matter at the dose of $4.0 \mathrm{~g} \mathrm{~L}^{-1}$ of the slow-release fetilizer in the container volume of $2.2 \mathrm{~L}$, showing a $57.6 \%$ increase, when compared to the container volume of $1.8 \mathrm{~L}$, at the dose of $4.0 \mathrm{~g} \mathrm{~L}^{-1}$ of controlledrelease fetilizer (Figure 3A). This result is probably proportionally related to the container volume, as well as to the availability of a greater space for root growth, ensuring a greater expansion of the root system and use of nutrients.

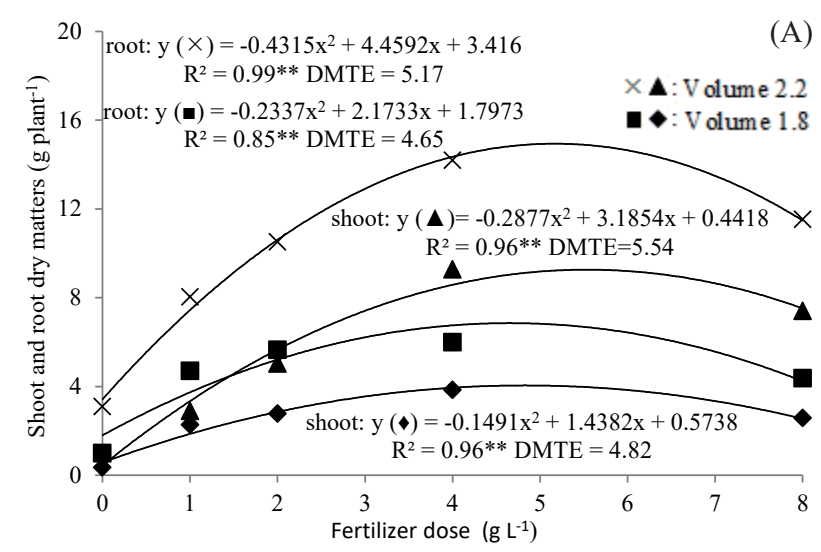

The other reason for the promotion of plant growth by changing the $\mathrm{N}^{+}$ratio could be that, after the nitrate reductase reduced $\mathrm{NO}_{3}^{-}$to nitrite, it was changed to ammonium, and amino acids were produced, which can later combine to produce proteins (Haghighi et al. 2012). On the other hand, nitrate, by producing active forms of cytokinins, as osmolyte in vacuoles, stimulates the leaf function and growth, causing cell extension and improved growth (Wang et al. 2008). The increasing root length and cytokinin production helped the plant to absorb more water and nutrients to improve its vegetative growth (Haghighi et al. 2016).

According to Damasceno et al. (2019), shoot dry matter is an indicator of the rusticity of a seedling. In the present study, the maximum technical efficiency dose was obtained in plants grown in the container volume of $2.2 \mathrm{~L}$, at a dose around $5.5 \mathrm{~g} \mathrm{~L}^{-1}$ of the fetilizer (Figure $3 \mathrm{~A}$ ). This combination provided more

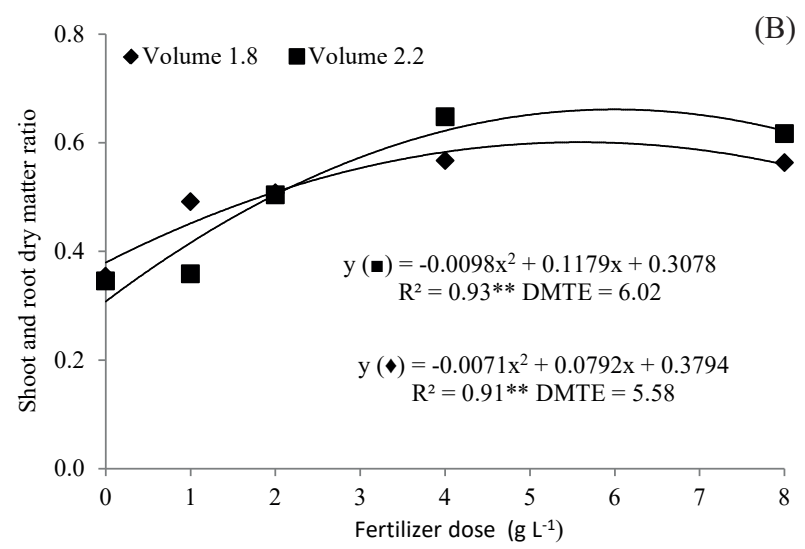

Figure 3. Shoot and root dry matters (A) and the ratio between them (B) in Agonandra brasiliensis seedlings, as a function of controlled-release fertilizer doses and container volumes, under nursery conditions. 
lignified and rustic seedlings, which have a greater guarantee of establishment and survival in the field.

For the ratio between the shoot and root dry matters, the maximum technical efficiency dose of the controlled-release fertilizer, regarding the best container volume (2.2 L), was $6.02 \mathrm{~g} \mathrm{~L}^{-1}$ (Figure 3B). Despite this maximized response, Cabreira et al. (2017) warned that, in forest species, high fertilization doses may lead to an unbalanced growth of seedlings (high values for this ratio), with toppling and reducing of water and nutrient absorptions. Hence, it is worth taking into account lower doses, such as $2.0 \mathrm{~g} \mathrm{~L}^{-1}$ (with the ratio reduced in around $30 \%$ ), that still had a positive effect, when compared to the control, and require a smaller amount of inputs.

According to Yang et al. (2018), nutrient and water deficiencies decrease the ratio between shoot and root dry matters, as it has a greater effect on shoot growth, due to the essential functions of the root system. Any change in the architecture of the root system may modify the capture and allocation of resources and growth of plants, what is corroborated by results of this study. On the other hand, under favourable conditions of water and nutrient availability, air and soil temperature, and a suitable container volume, among others, the roots will show a greater growth, making possible the exploitation of new areas of soil and increasing the supply of nitrogen, phosphorus and potassium for the plants. Therefore, a controlled-release fertilizer formulation, such as the one used in this study, allows a better balance between the shoot and root systems.

A gradual increase was observed for total dry matter, as a function of a dose up to a maximum technical efficiency at $5.31 \mathrm{~g} \mathrm{~L}^{-1}$ of the controlledrelease fertilizer, followed by a decrease at the dose of $8 \mathrm{~g} \mathrm{~L}^{-1}$ (Figure 4A), irrespective of container volume. Although a leaf-area analysis was not carried out, studies show that an increase in the number of leaves per plant correlates directly with an increase in the leaf area (Menegatti et al. 2017a), offering a greater efficiency in the capture of solar energy for photosynthesis and the production of photoassimilates, resulting in a greater total dry weight (Souza et al. 2020). This is shown in Figure 4, for plants grown in a container volume of $2.2 \mathrm{~L}$. This condition gave a maximum plant growth in less time, ultimately reducing the length of stay in the nursery.

The maximum increase in the dry weight production among the plant organs is the result (more than $90 \%$ ) of photosynthetic carbon assimilation (Lopes \& Lima 2015), with the energy and carbon skeletons incorporating the nitrogen coming from carbon metabolism and the production of new tissues controlled by the nitrogen present in the controlledrelease fetilizer formulation used in this study.

The quality of the seedlings was also estimated using the Dickson Quality Index. The highest estimate was obtained for plants grown in the container volume of $2.2 \mathrm{~L}$, at the dose of $4.0 \mathrm{~g} \mathrm{~L}^{-1}$ of the controlled-release fetilizer (Figure 4B) incorporated into the medium-sand substrate, and, as a result, the seedlings from this treatment were considered superior, with a more balanced growth. According to Menegatti et al. (2017b), this index is a good indicator of initial seedling survival in the field, as it considers important characteristics in evaluating the quality of
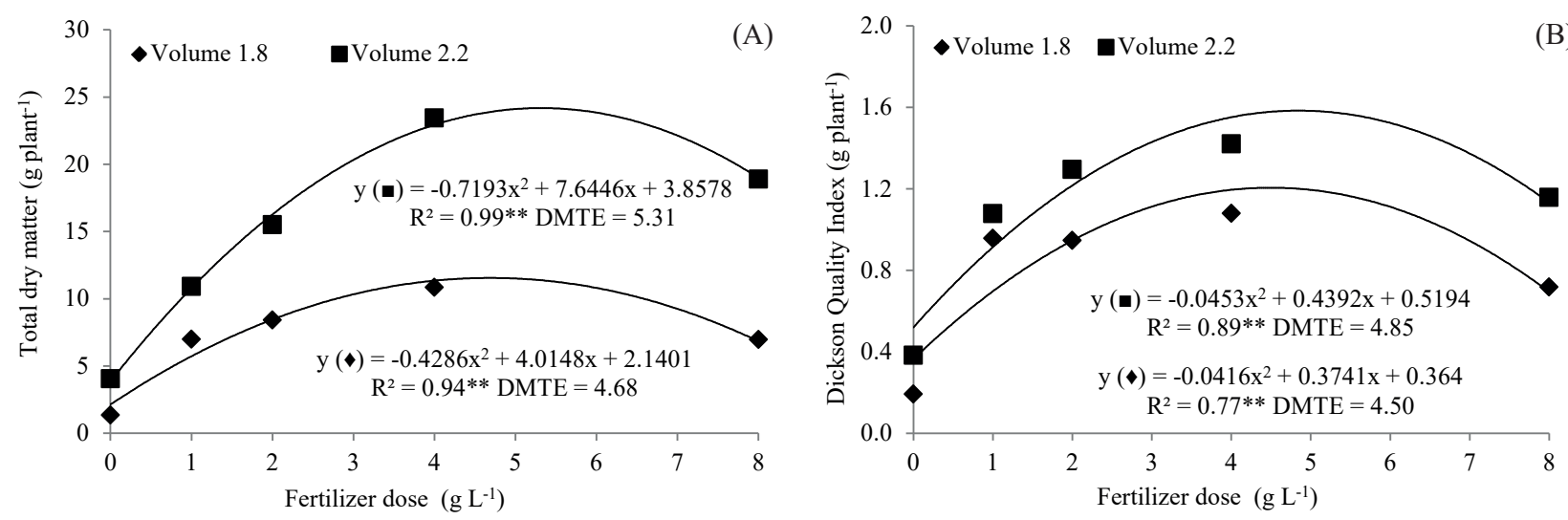

(B)

Figure 4. Total dry matter (A) and Dickson Quality Index (B) in Agonandra brasiliensis seedlings, as a function of controlled-release fertilizer doses and container volumes, under nursery conditions. 
the seedlings to be transplanted, including robustness and biomass distribution balance.

According to Pinto et al. (2020), these results are of great interest to producers of forest seedlings, since there is an increase in the quality of the produced seedlings, what is an advantage at the time of planting, when better quality seedlings tend to become established more quickly with an improved growth in the field, besides helping to minimize production costs.

Overall, the use of the controlled-release fetilizer incorporated to the medium-sand substrate, at doses of maximum technical efficiency and into containers of $2.2 \mathrm{~L}$, allowed the seedlings to show a superior performance and accelerated growth, when compared to the treatment without application of the fertilizer or with the doses of $1.0 \mathrm{~g} \mathrm{~L}^{-1}$ and $8.0 \mathrm{~g} \mathrm{~L}^{-1}$.

Similarly to the results obtained herein, other studies also confirm that controlled-release fertilizers induce a superiority in height, in addition to promote a greater production of shoot dry matter in seedlings of several forest species (Dutra et al. 2016, Menegatti et al. 2017a, Smiderle et al. 2020). This type of fertilizer is described as an effective input on the greenhouse phase, because it induces an efficiency in the physiological processes that promote the fast initial growth of the plants (Ao et al. 2018, Araújo et al. 2019). This fact shows, therefore, a strategic way of minimizing the operational costs of seedling production without leaving aside the quality standard.

\section{CONCLUSION}

The quality of Agonandra brasiliensis seedlings, grown on washed medium-sand substrate, is improved with the use of controlled-release fertilizer (Forth Cote ${ }^{\mathrm{TM}}$ - formulation NPK 15-09-12), especially at doses around $5.0 \mathrm{~g} \mathrm{~L}^{-1}$ in a $2.2 \mathrm{~L}$ container, which stimulates the seedling growth (shoot length and stem diameter) with a greater production of total dry matter.

\section{ACKNOWLEDGMENTS}

The authors thank the graduate program of the Universidade Federal de Roraima (UFRR - POSAGRO) and Embrapa Roraima, for the partnership; and the Conselho Nacional de Desenvolvimento Científico e Tecnológico $(\mathrm{CNPq})$, for the productivity and research scholarships granted to the first and fourth authors.

\section{REFERENCES}

AGUILAR, M. V. M.; MASSAD, M. D.; DUTRA, T. R.; MENEZES, E. S.; SANTOS, A. R.; SILVA, F. G. Produção de mudas de Albizia lebbeck (L.) Benth sob diferentes formulações e doses de Osmocote ${ }^{\circledR}$. BIOFIX Scientific Journal, v. 5, n. 1, p. 153-160, 2020.

AO, Y.; HIRST, P. M.; LI, G.; ZHANG, R. Combined effects of provenance and slow-release fertilizer on nursery and field performance of yellowhorn seedlings. Silva Fennica, v. 52, n. 2, p. 110-117, 2018.

ARAÚJO, J. M.; ANDRADE, N. R. C.; OLIVEIRA J. R.; LUNZ, A. M. P.; ALMEIDA, U. O. Shading and slow release fertilizer effects on the growth characteristics of açai seedlings (Euterpe oleracea). Floresta e Ambiente, v. 26, n. 3, p. 31-39, 2019.

BELING, R. R. (ed.). Anuário brasileiro da silvicultura. Santa Cruz do Sul: Gazeta Santa Cruz, 2016.

BRITO, L. P. S.; BEZERRA, T. T. B.; NUNES, E. M. B.; CAVALCANTE, M. Z. B.; SIQUEIRA FILHO, J. A. Production of Schinopsis brasiliensis Engler seedlings under washed coconut coir fiber and increasing doses of controlled release fertilizers. Ciência Florestal, v. 28, n. 3, p. 1022-1034, 2018.

CABREIRA, G. V.; LELES, P. S. S.; ARAÚJO, E. J. G.; SILVA, E. V.; LISBOA, A. C.; LOPES, L. N. Produção de mudas de Schinus terebinthifolius utilizando biossólido como substrato em diferentes recipientes e fertilizantes. Scientia Agraria, v. 18 , n. 2, p. 30-42, 2017.

CONFEDERAÇÃO NACIONAL DA INDÚSTRIA (CNI). Florestas plantadas: oportunidades e desafios da indústria de base florestal no caminho da sustentabilidade. Brasília, DF: CNI, 2017.

DAMASCENO, A. S. S.; BOECHAT, C. L.; MORAIS, J.; GONÇALVES, B. P. S.; ARAUCO, A. M. S. Soil classes and regional organic residues affect nutrition, morpho-physiology and quality of copaiba seedlings. Cerne, v. 25, n. 2, p. 131-139, 2019.

DICKSON, A.; LEAF, A. L.; HOSNER, J. F. Quality appraisal of white spruce and white pine seedling stock in nurseries. Forest Chronicle, v. 36, n. 2, p. 10-13, 1960.

DUTRA, T. R.; MASSAD, M. D.; SARMENTO, M. F. Q.; MATOS, P. S.; OLIVEIRA, J. C. Fertilizante de liberação lenta no crescimento e qualidade de mudas de canafístula (Peltophorum dubium (Spreng.) Taub.). Floresta, v. 46, n. 4, p. 491-498, 2016.

ELLI, E. F.; CARON, B. O.; MONTEIRO, G. C.; PAVAN, M. A.; PEDRASSANI, M.; CANTARELLI, E. B.; ELOY, E. Osmocote ${ }^{\circledR}$ no desenvolvimento e comportamento fisiológico de mudas de pitangueira. Comunicata Scientiae, v. 4, n. 4, p. 377-384, 2013. 
FERREIRA, D. F. Sisvar: a guide for its bootstrap procedures in multiple comparisons. Ciência e Agrotecnologia, v. 38, n. 2, p. 109-112, 2014.

HAGHIGHI, M.; HEIDARIAN, S.; TEIXEIRA, J.; SILVA, D. A. A. The effect of titanium amendment in $\mathrm{N}$-withholding nutrient solution on physiological and photosynthesis attributes and micro-nutrient uptake of tomato. Biological Trace Element Research, v. 150, n. 3, p. 381-390, 2012.

HAGHIGHI, M.; MOHAMMADNIA, S.; PESSARAKLI, M. Effects of mycorrhiza colonization on growth, root exudates, antioxidant activity and photosynthesis trait of cucumber grown in Johnson modified nutrient solution. Journal of Plant Nutrition, v. 39, n. 3, p. 2079-2091, 2016.

INDÚSTRIA BRASILEIRA DE ÁRVORES (IBÁ). Relatório anual. 2017. Disponível em: http://iba.org/ images/shared/Biblioteca/IBA_RelatorioAnual2017.pdf. Acesso em: 29 jan. 2020.

LOPES, N. F.; LIMA, M. G. S. Fisiologia da produção. Viçosa: Ed. UFV, 2015.

MASSAD, M. D.; DUTRA, T. R.; MEIRELES, I. E. S.; SARMENTO, M. F. Q.; SANTOS, A. R.; MENEZES, E. S. Avaliação do crescimento de canafístula em diferentes densidades de mudas por bandeja e volumes de tubetes. Ecologia e Nutrição Florestal, v. 5, n. 1, p. 1-9, 2017.

MATIAS, S. S. R.; COSTA JUNIOR, E. S.; MORAIS, D. B.; SILVA, R. L.; SOUSA, S. J. C. Substratos orgânicos na produção de mudas do mamoeiro havaí. Magistra, v. 30, n. 2, p. 179-188, 2019.

MENEGATTI, R. D.; GUOLLO, K.; NAVROSKI, M. C.; VARGAS, O. F. Fertilizante de liberação lenta no crescimento inicial de Aspidosperma parvifolium A. DC. Scientia Agraria Paranaensis, v. 1, n. 2, p. 45-49, 2017 a.

MENEGATTI, R. D.; NAVROSKI, M. C.; GUOLLO, K.; FIOR, C. D.; SOUZA, A. G.; POSSENTI, J. C. Formação de mudas de guatambu em substrato com hidrogel e fertilizante de liberação controlada. Revista Espacios, v. 38, n. 22 , p. $35-47,2017$ b.

MOARES, K. N. O.; ALMEIDA, M. C.; PINHEIRO, R. M.; DIAS, M. R. Q. Avaliação biométrica de sementes de Agonandra brasiliensis Miersex Benth. \& Hook. f. (Opiliaceae). South American Journal of Basic Education, Technical and Technological, v. 5, n. 1, p. 170-176, 2018.

PIAS, O. H. C.; BERGHETTI, J.; SOMAVILLA, L.; CANTARELLI, E. B. Produção de mudas de cedro em função de tipos de recipiente e fontes de fertilizante. Pesquisa Florestal Brasileira, v. 35, n. 82, p. 153-158, 2015.

PINTO, C. E. D. L.; FAJARDO, J. D. V.; TAUBE, P. S.; SACRAMENTO, J. A. A. S.; BARROS, E. C. Initial production and quality of camu-camu fruits under organic and mineral fertilization. Pesquisa Agropecuária Tropical, v. 50, e60821, 2020.
ROSSA, Ü. B.; ANGELO, A. C.; NOGUEIRA, A. C.; WESTPHALEN, D. J.; BASSACO, M. V. M.; MILANI, J. E. F.; BIANCHIN, J. E. Fertilizante de liberação lenta no desenvolvimento de mudas de Schinus terebinthifolius e Sebastiania commersoniana. Floresta, v. 43, n. 1, p. 93104, 2013.

ROSSA, Ü. B.; ANGELO, A. C.; WESTPHALEN, D. J.; OLIVEIRA, F. E. M.; SILVA, F. F.; ARAUJO, J. C. Fertilizante de liberação lenta no desenvolvimento de mudas de Anadenanthera peregrina (L.) Speg. (angicovermelho) e Schinus terebinthifolius Raddi (aroeiravermelha). Ciência Florestal, v. 25, n. 4, p. 841-852, 2015.

SERRANO, L. A. L.; FANTON, C. J.; GUARÇONI, M. A. Substratos orgânicos e adubo de liberação lenta na produção de mudas de cajueiro-anão-precoce. Fortaleza: Embrapa Agroindústria Tropical, 2012.

SERRANO, L. A. L.; HAWERROTH, F. J.; TANIGUCHI, C. A. K.; MELO, D. S. Substratos comerciais e adubo de liberação lenta (NPK 14-14-14) na produção de portaenxerto de cajueiro. Fortaleza: Embrapa Agroindústria Tropical, 2013.

SMIDERLE, O. J.; SOUZA, A. G.; MENEGATTI, R. D. Controlled-release fertilizer in the production of seedlings of Anonna cacans Warm. Journal of Agricultural Studies, v. 8 , n. 3, p. 125-133, 2020.

SMIDERLE, O. J.; SOUZA, A. G.; SCHWENGBER, L. A. M.; SCHWENGBER, D. R. Shading of seedlings of pau-rainha and the use of fertilized substrate. Revista Espacios, v. 38, n. 34, p. 1-9, 2017.

SOUZA, A. G.; SMIDERLE, O. J.; ARAUJO, R. M.; MORIYAMA, T. K.; DIAS, T. J. Controlled-release fetilizer and substrates on seedling growth and quality in Agonandra brasiliensis in Roraima. Journal of Agricultural Studies, v. 8, n. 3, p. 70-80, 2020.

SOUZA, A. G.; SMIDERLE, O. J.; CHAGAS, E. A. Nutrition and accumulation of nutrients in Pochota fendleri seedlings. Revista Brasileira de Ciências Agrárias, v. 13, n. 3, p. 1-7, 2018.

STÜPP, Â. M.; NAVROSKI, M. C.; FELIPPE, D.; KNIESS, D. D. C.; AMANCIO, J. C.; SILVA, M. A.; PEREIRA, M. O. Crescimento de mudas de Mimosa scabrella Benth em função de diferentes tamanhos de recipientes e doses de fertilizante. Ecologia e Nutrição Florestal, v. 3, n. 2, p. 40-47, 2015.

WANG, H.; WU, L.; ZHU, Y.; TAO, Q. Growth, nitrate accumulation, and macronutrient concentration of pakchoi as affected by external nitrate-n:amino acid-n ratio. Journal Plant Nutrition, v. 31, n. 4, p. 1789-1799, 2008.

YANG, H.; LI, S.; SUN, H.; WANG, W.; ZHAO, F. Effects of substrate material on plant growth and nutrient loss. Polish Journal of Environmental Studies, v. 27, n. 6, p. 2821-2832, 2018. 